\title{
15. An all-European conversation: Promoting a common understanding of European human rights
}

\section{András Sajó}

No modern institution can survive exclusively on status-based authority. It is criticism that generates and maintains the self-reflection that enables adaptation and initiative. The European Court of Human Rights ('ECtHR' or 'the Court') certainly needs and often deserves criticism. Only self-reflection - generated by honest criticism - enables performance improvement both in terms of intellectual integrity and functional efficiency. The Court has to be grateful for criticism and for the efforts of the human rights, academic and political communities dedicated to 'Court-watching'. This term is derived from 'bird-watching', which is based on conservationist principles and aims to protect and assist the life of birds. The methods used in bird-watching are praiseworthy and to be emulated, particularly in contemporary times, as it appears that some of the Court's critics are more interested in 'Court-watching' for the purposes of hunting rather than conserving.

This chapter addresses select points related to the current problems facing the Court and some of the potential remedies to those problems. The issues dealt with are:

I. The issue of the backlog of applications, which cannot be discussed exclusively in terms of excess in the number of applications (meritorious or otherwise);

II. The difficulties of the Court related to the structural shortcomings at the national level;

III. States Parties are not ideally positioned to 'save' the Court, but they may have an interest in improving the situation at the domestic level, in accordance with the subsidiarity principle; 
IV. Though there can be no improvement in case management without additional resources allocated to the Court, no reform will be successful without granting independence to the Court; and, finally,

V. An improvement to the Court's work presupposes a proper form of cooperation between the Court and national judiciaries and authorities.

\section{BACKLOG OF APPLICATIONS}

The Court's current difficulties are often described in terms of case overload. There has been a considerable increase in the Court's caseload since the entry into force of Protocol No. 11 to the European Convention on Human Rights ('ECHR' or 'the Convention'). ${ }^{1}$ The Court delivered fewer than 1,000 judgments between 1959 and 1998, while the number of judgments delivered in the period 1999 to 2011 exceeds 14,000..$^{2}$ Its output is such that more than 91 per cent of the Court's judgments since its creation in 1959 have been delivered between 1998 and 2011. The number of new applications allocated to a judicial formation has increased substantially over the last twelve years $(8,400$ in 1999 , compared with 64,500 in 2011). ${ }^{3}$ A consequence of the increasing number of applications is the vast amount of pending cases (at present around $140,000)^{4}$ and a potentially excessive length of proceedings before the Court.

This backlog derives from a number of causes. Firstly, in many member States there is no adequate domestic mechanism to protect certain fundamental rights, so the Court has had to protect these rights at the international level. Even where the Court has found a violation, there is not always an effective remedy granted at the national level. It is clear that the Committee of Ministers has its own obligations under the ECHR in this regard, but the Court too must consider some kind of general

1 Protocol No. 11 to the Convention for the Protection of Human Rights and Fundamental Freedoms (opened for signatures 11 May 1994 and entered into force on 1 November 1998).

2 European Court of Human Rights, Annual Report 2011 (Strasbourg 2012) page 14; and European Court of Human Rights, Survey of 40 years of activity 1959-1998 (23 September 1998) page 26.

3 European Court of Human Rights, Annual Report 2011 (Strasbourg 2012) page 14 .

4 European Court of Human Rights, Pending Applications Allocated to a Judicial Formation (Strasbourg 30 September 2012). 
remedy in case of a structural problem in a member State. It is unfair to blame the applicants for the overload.

Secondly, many of the specific human rights conventions available in the international arena do not have correlating judicial enforcement bodies to protect the rights enshrined therein. Therefore, the European Court of Human Rights has had to take up the role of reading into the Convention to protect a variety of rights. For example, consider issues of child abduction or refugee law. ${ }^{5}$ An additional factor regarding the increase of the Court's caseload as well as a source of tension, is the fact that some national courts fail to read human rights obligations into these international conventions. Much of the unfinished business of international (human rights and other) conventions has ended up in the backyard of the European legal system, i.e. in Strasbourg.

\section{STRUCTURAL SHORTCOMINGS AT A NATIONAL LEVEL}

The reforms so far were to some extent pragmatic and technical without taking a broader, value oriented perspective. While the backlog of applications has a number of organisational and structural causes and shall be dealt with accordingly, it is also related to more general issues of values. Reform to solve the Court's overload began in 2001. Protocol No. 14 ECHR was an important element of that reform. Its purpose was to guarantee the long-term efficiency of the Court by optimising the screening and processing of applications. After a long period of pending status and the temporary Protocol No. 14bis and the Madrid Agreement, the Protocol came into force on 1 June 2010.6 Despite noting the encouraging results and efficiencies due to Protocol No. 14 ECHR, the member States' 2012 Brighton Declaration emphasised that the growing number of potentially well-founded applications pending before the

5 Neulinger and Shuruk v. Switzerland App no 41615/07 (ECHR 6 July 2010); and Vincent Chetail, 'Le Droit des Réfugiés à l'Épreuve des Droits de l'Homme: Bilan de la Jurisprudence de la Cour Européenne des Droits de l'Homme sur l'Interdiction du Renvoi des Étrangers Menacés de Torture et de Traitements Inhumains ou Dégradants', (2004) Revue Belge de Droit International 37, 155-210.

6 Protocol No. 14 to the European Convention on Human Rights and Fundamental Freedoms (opened for signature on 13 May 2004 and entered into force on 1 June 2010). 
Court remains a serious and unresolved problem. ${ }^{7}$ Therefore, further measures are necessary to ensure a comprehensive solution to this problem facing the Convention system.

The European Convention on Human Rights emanates from a fundamental ambition of Europe to form a community of values and reflects an understanding of a Europe based on a shared value of human rights. This is a self-imposed vision of the member States and not an elitist view from the Court at Strasbourg. The Convention was not only a reaction to the Second World War, or a reaction to the Soviet threat: it was a grand plan, and if it was not, it became a grand plan through enduring interaction. The creation of an international human rights mechanism was a longterm project; it was the expression of a willingness to accept Europe as unified by a common understanding of human rights. The current criticism of the Court cannot be answered without taking into consideration the very nature of the international human rights protection mechanism that was envisioned for Europe. Moreover, it cannot be answered without placing the Court's difficulties in the context of the current tension at the national level in human rights protection.

States Parties have agreed, pursuant to their obligations under Article 1 ECHR, to secure to everyone within their jurisdiction the rights and freedoms defined in the Convention and to provide an effective remedy before a national authority for everyone whose rights and freedoms are violated. However, States enjoy a choice as to the modalities of the realisation of the Convention, depending on the circumstances of each case. ${ }^{8}$ As such, the protection of rights provided by the Court is subsidiary to the safeguarding of rights at the national level - noting that the margin of appreciation granted to national authorities needs to be supervised by Strasbourg. ${ }^{9}$ The role of the international mechanism set up by the Convention is to ensure that States implement the Convention correctly and, therefore, the Court reviews the compatibility of decisions taken by national authorities with the Convention.

7 European Court of Human Rights, High Level Conference on the Future of the European Court of Human Rights, Brighton Declaration (20 April 2012) para 6.

8 Pieter van Dijk, Fried van Hoof, Arjen van Rijn and Leo Zwaak (eds), Theory and Practice of the European Convention on Human Rights, 4th edition (Antwerp and Oxford 2006) page 28.

9 The point that the margin of appreciation is subject to European supervision was already made by the Court in Handyside v. The United Kingdom App no 5493/72 (ECHR 4 November 1976) para 49. 
In order to reach a high level of protection of human rights, responsibility for securing the rights guaranteed in the Convention is shared between States and the Court (and other Convention mechanisms). Therefore, member States and the Court must work in partnership and initiate dialogue. The Convention system is based on the principle of cooperation where politicians and domestic authorities accept the need for common supervision of human rights in Europe. Both domestic authorities and the Court are necessary for the efficient protection of rights as one cannot rely solely on either the State or the Court. According to this important relationship, the system is based on the assumption of mutual support.

The current revival of the idolatry of nation state sovereignty does not favour international human rights protection as a shared European interest. The Court faces increased pressure as some contend that the Court is abusing sovereign powers and chipping away at the national legislature. This is dubious criticism. After all, modern constitutional theory stands for the separation of powers and accepts that courts have a proper role in countering national parliaments. ${ }^{10}$ These considerations of counter-balancing power apply in comparable ways at the international level. Hence, international courts play a legitimate role in countering the one-sidedness of national parliaments. Moreover, the Convention is an international treaty that sovereign States have freely accepted. The decision-making power of the Court derives from the member States' sovereignty and includes the undertaking of international obligations concerning human rights. Therefore, state sovereignty and the jurisdiction of the Court are properly compatible.

\section{PRIMARY STATE RESPONSIBILITY AND THE SUBSIDIARITY PRINCIPLE}

The High Level Conferences on the future of the Court since 2010 and the respective Declarations ${ }^{11}$ indicate that further steps are required to sustain the long-term effectiveness of the Convention mechanism. These efforts shall take into account the nature of judicial work and, in

10 John Hart Ely, Democracy and Distrust, A Theory of Judicial Review (Cambridge 1980).

11 See the Interlaken (2010), Izmir (2011) and Brighton Declarations (2012). European Court of Human Rights, Reform of the Court $<$ http://www.echr.coe.int/ ECHR/EN/Header/The+Court/Reform+of+the+Court/Conferences/> accessed on 20 October 2012. 
particular, the fact that a court can work only as an independent institution. Member States are the masters of the Convention, however, they suffer inevitably and permanently from a somewhat odd conflict of interest: they have Conventional obligations to provide an efficient system nationally and internationally, while at the same time they are respondents in the Court's proceedings with the understandable interest to avoid being found in violation of the Convention. This presents an inherent difficulty in the Convention system that must also be considered when amendments are proposed to the Court or when criticism is made by member States.

\section{RESOURCES AND INDEPENDENCE OF THE COURT}

It is often argued that the shortcomings and overburdening of the Court are related to the Court's limited capacities and its inability to handle the overflow. Therefore, the problem is discussed in terms of insufficient resources allocated to the Court. The inadequacy of the Court's budget is a genuine problem. However, we should go beyond the discussion of insufficiency of resources and ensure that the inadequacy of rights protection at the national level is not left out of the equation.

The blame game should, however, be bypassed. One cannot understand the present problems and the possible remedies without considering the issue of the Court's independence. This is a neglected issue. For example, the Interlaken Declaration refers to the importance of maintaining the independence of judges and of preserving the impartiality and quality of the Court, but considers it as a problem of proper 'staffing'. The Declaration calls upon member States and the Council of Europe to 'ensure, if necessary by improving the transparency and quality of the selection procedure at both national and European levels, full satisfaction of the Convention's criteria for office as a judge of the Court, including knowledge of public international law and of the national legal systems as well as proficiency in at least one official language.' ${ }^{12}$ Equally, the 2012 Brighton Declaration again addresses the quality of the Court's judges. ${ }^{13}$

12 European Court of Human Rights, High Level Conference on the Future of the European Court of Human Rights, Interlaken Declaration (19 February 2010) para 8(a).

13 Brighton Declaration (20 April 2012) supra n 7, Part E. 
But there is little evidence that the quality of judges lies at the heart of the Court's current difficulties. There is no evidence in the scholarly literature of national bias in the Court's judgments and, on the contrary, scholarly studies indicate the personal integrity of the judges. The Court takes conscious measures to avoid national bias and the prevailing judicial ethics offer additional safeguards, although material conditions are unsatisfactory. The independence problem lies at a different level; it is an institutional problem. The Court is embedded in an international bureaucracy that is dependent (to a limited extent) on its clients (i.e. the member States).

At least in principle, the member States have recognised that a high level of independence and impartiality of the Court and its judges is necessary for the performance of the judicial function and for an effective review of human rights violations. ${ }^{14}$ However, in practical terms this recognition has only resulted in a statement in the Interlaken Declaration that the necessary level of administrative autonomy be granted to the Court in order to function in an efficient way within the Council of Europe. ${ }^{15}$ After all, the Court is a 'creature' of the Convention and not of the Council of Europe. The Court's independence and impartiality must be unequivocally recognised and reinforced by concrete guarantees beyond administrative autonomy. The adequate mechanisms are well known in constitutional law.

\section{COOPERATION BETWEEN THE COURT AND NATIONAL JUDICIARIES AND AUTHORITIES}

As a matter of course, the Court is not the only player in the transnational human rights interaction. The European Court cannot replace domestic courts. Due consideration of the Convention and the Court's jurisprudence in national courts is of paramount importance, even if the Court's judgments remain declaratory. According to the Brighton Declaration, 'National courts and tribunals should take into account the Convention and the case law of the Court. Collectively, these measures should reduce the number of violations of the Convention. They would also reduce the number of well-founded applications presented to the Court, thereby

\footnotetext{
14 See e.g. Article 46(1) ECHR: 'The High Contracting Parties undertake to abide by the final judgments of the Court in any case to which they are parties'.

15 Interlaken Declaration (19 February 2010) supra n 12, para 8(b).
} 
helping to ease its workload.' ${ }^{16}$ However, there is no international roadmap for the effective national implementation of the Convention.

There is a growing emphasis that national courts and tribunals should take 'into account the relevant principles of the Convention, having regard to the case law of the Court, in conducting proceedings and formulating judgments; and in particular enabling litigants, within the appropriate parameters of national judicial procedure but without unnecessary impediments, to draw to the attention of national courts and tribunals any relevant provisions of the Convention and jurisprudence of the Court' ${ }^{17}$ After a serious and honest 'consideration', within the limits of the national constitutional system, courts have to apply the jurisprudence of the Court; otherwise they run the risk of violating the Convention. There is currently no consideration of a direct international obligation to apply the jurisprudence of the Court erga omnes in national proceedings as a matter of domestic constitutional law, although there is remarkable national experience demonstrating that this would be feasible. Such an effective implementation at the national level would reduce the Court's caseload and make it easier for the Court to maintain an appropriate distance from national proceedings in full compliance with the principle of subsidiarity.

A dialogue between Strasbourg and national courts is essential for an appropriate interpretation of the Convention and the Court's case law by national courts. Some States have expressed interest in a procedure that would allow the highest national courts to request advisory opinions from the European Court concerning the interpretation and application of the Convention. ${ }^{18}$ In order to maintain the European human rights system, national courts also need to enter into the dialogue. Perhaps we should move away from a dialogue, a bilateral effort by definition, and towards an all-European conversation.

One possibility is that the procedure (case management) itself relies more on subsidiarity, providing the States with additional opportunities to recognise potential violations and provide adequate remedies. Some kind of repatriation of the applications might be an appropriate answer. Where a case falls into the purview of well-established case law broadly construed, once the case is deemed admissible by a single judge (or even with an administrative finding of prima facie admissibility), the case could be sent back to the relevant government with the expectation that the

\footnotetext{
16 Brighton Declaration (20 April 2012) supra n 7, para 7.

17 Ibid, para 9(c)(iv).

18 Ibid, para $12(\mathrm{~d})$.
} 
government provide a remedy where the law and/or the principle is clear. The State should be provided the first opportunity to remedy the violation. Certain methods and procedures such as unilateral declarations, friendly settlements and pilot judgment procedures are also a step forward. ${ }^{19}$

Amongst the flood of applications, the Court should be able to focus its attention on the most important and serious cases. The Court, therefore, decided to adopt a new policy towards applications - the priority policy. ${ }^{20}$ While earlier cases had been processed and adjudicated principally on a chronological basis, after the amendment of the Rules of Court in 2009, the Court now has regard to the importance and urgency of the issues raised in the application when determining the order in which to deal with cases. ${ }^{21}$ To implement this policy the Court has drawn up a number of different categories, so that a case in a higher category is examined before a case in a lower category - although the Chamber or its President may derogate from the criteria so as to give priority to a particular application. The purpose of this policy is to ensure that the most important cases and the potentially well-founded violations are dealt with more rapidly.

\section{CONCLUSION: THE WAY FORWARD FOR EUROPEAN HUMAN RIGHTS}

In a way, Strasbourg is a forum of interaction, an emerging common space between all European courts. The European Court of Human Rights takes part in the trans-judicial dialogue by providing inspiration for national courts and in turn being inspired by them. The longer-term vision must secure the viability of the European Court's role in the system for protecting and promoting human rights across Europe. The future of the Court depends on the understanding of what human rights are about in Europe. It can be a common future only if we wish to have such a future for Europe.

19 Philip Leach, Helen Hardman and Svetlana Stephenson, 'Can the European Court's Pilot Judgment Procedure help Resolve Systemic Human Rights Violations? Burdov and the Failure to Implement Domestic Court Decisions in Russia', (2010) Human Rights Law Review 10, 346-359.

20 European Court of Human Rights, The Court's Priority Policy <http:// www.echr.coe.int/NR/rdonlyres/DB6EDF5E-6661-4EF6-992E-F8C4ACC62F31/ 0/Priority_policyPublic_communication_EN.pdf> accessed on 20 October 2012.

21 The policy has been expressed in Rule 41 of the Rules of Court. 